ISSN. 2442-6962

Vol. 10. No. 1 (2021)

\title{
Representasi Gender Inequality dalam Film Kim Ji-Young, Born 1982 (Analisis Wacana Kritis Sara Mills)
}

\author{
Ira Kaestiningtyas ${ }^{1}$, Anaziah Safitri ${ }^{2}$, Ghina Fadhilah Amalia ${ }^{3}$ \\ 1,2,3 Program Studi Ilmu Komunikasi, UPN "Veteran“ Jawa Timur \\ Email : ghinfaml@gmail.com
}

\begin{abstract}
Gender inequality refers to unequal treatment or perceptions of individuals based on their gender. This situation occurs more common in countries that still uphold of patriarchal system in their social structure where men hold the highest position in daily and it was considered appropriate to discriminate women as they dominate them. As it seems in "Kim Ji-young, Born 1982", a film that tried to speak up about gender issue that has been happened in South Korea. The method used in this research is descriptive qualitative to analyze how they portrayed gender inequality through research method with the approach of critical discourse analysis by Sara Mills. The conclusion of this article is as mass media, film has roles to entertain, to inform, to persuade, and to educate people. And yet in this case also to reveal the reality about how women are treated as weaklings in society and it is inevitable for women to face gender inequality.
\end{abstract}

Keywords: Critical Discourse Analysis, Film, Gender, Gender Inequality, Sara Mills

\begin{abstract}
Abstrak. Ketidaksetaraan Gender merupakan suatu kondisi dimana terjadi ketidakadilan atau perbedaan antara laki-laki dan perempuan hingga muncul diskriminatif. Keadaan ini lebih banyak terjadi di negara yang memegang teguh struktur sosial patriarkhi, dimana laki-laki mempunyai kedudukan tertinggi pada seluruh kehidupan dan dianggap patut untuk mendominasi dan mendeskriditkan kaum perempuan. Seperti halnya dalam film Kim Ji-young, Born 1982 yang mencoba mengangkat isu gender yang terjadi di Korea Selatan. Menggunakan meode deskriptif kualitatif penelitian ini mengupas nilai-nilai ketidaksetaraan gender melalui pendekatan teori analisis wacana kritis cetusan Sara Mills. Simpulan dari tulisan ini yaitu film sebagai media massa memperlihatkan realitas bagaimana perempuan dalam konstruk sosial diperlakukan sebagai sosok yang lemah dan tidak terelakkan dari ketimpangan akibat dari ketidakadilan gender yang membudaya di masyarakat.
\end{abstract}

Kata Kunci: Analisis Wacana Kritis, Film, Gender Ketidaksetaraan Gender, Sara Mills

\section{PENDAHULUAN}

Dewasa ini isu-isu gender seperti ketidaksetaraan gender (gender inequality) bukanlah suatu hal yang tabu untuk diperbincangkan. Lahirnya teori-teori feminisme dan para aktivis pejuang kesetaraan gender mendatangkan dampaknya ke masing-masing sektor apalagi di tengah era globalisasi, teknologi informasi dan komunikasi semakin diberi kemudahan dalam mengangkat topik tersebut ke hadapan audiens. Ketidaksetaraan Gender merupakan suatu kondisi dimana terjadi ketidakadilan atau perbedaan antara laki-laki dan perempuan hingga muncul diskriminatif. Berbagai macam bentuk ketidaksetaraan gender yaitu marjinalisasi, subordinasi, stereotype (pelabelan), violence (kekerasan), dan beban kerja. Ketimpangan ini bisa terjadi dalam berbagai sektor misalnya, sektor ekonomi, politik, hiburan, agama, sosial, budaya bahkan dalam sektor pendidikan. Peran perempuan kerap diremehkan dan dinilai tidak besar kontribusinya dibanding dengan laki-laki. Keadaan ini lebih banyak terjadi di negara yang memegang teguh struktur sosial patriarkhi, dimana laki-laki mempunyai kedudukan tertinggi pada seluruh kehidupan dan dianggap patut untuk memimpin dan mendiskriditkan kaum perempuan (Farnisari \& Sudrajat, 2013).

Film merupakan cermin kehidupan yang memiliki dualisme sebagai refleksi atau sebagai representasi masyarakat. Menurut Sumarno (1996) bahwa film yang baik adalah film yang mampu merepresentasikan kenyataan sosial pada zamannya. Artinya, film dihadirkan oleh para sineas sebagai 
ISSN. 2442-6962

Vol. 10. No. 1 (2021)

wujud dari representasi dan mozaik kehidupan masyarakat dalam wujud teks-teks atau narasi-narasi audiovisual yang dihadirkan kepada publik melalui bantuan seperangkat peralatan sinematik yang mencirikan zamannya. Dalam konteks komunikasi massa, film memiliki peran tidak hanya sebagai media penghibur. Selain mengandung fungsi hiburan, film juga mempunyai fungsi informasi, edukasi serta persuasive. Dilihat dari fungsi yang telah disebutkan, para sineas mengangkat tema perempuan dan gender karena film dinilai mampu memberikan pemahaman pada khalayak secara efektif melalui audiovisual serta jalan cerita yang difilmkan.

Isu gender yang masih sangat kental dan merupakan topik sensitif di Korea Selatan diangkat melalui film layar lebar berjudul Kim Ji-Young, Born 1982 oleh sutradara sekaligus penulis Kim Doyoung menuai banyak kecaman dari para aktivis anti-feminisme Korea Selatan. Meski demikian, Kim Ji-Young, Born 1982 rilis perdana pada tanggal 23 Oktober 2019 lalu, film ini diadopsi dari novel bestseller yang telah terbit di 19 negara berjudul sama karya Cho Nam-joo. Peran Kim Ji-young, tokoh utama dalam cerita dimainkan oleh Jung Yu-mi sementara peran Jung Dae-hyun selaku suami Kim Jiyoung dimainkan oleh Gong Yoo. Secara garis besar film ini menceritakan tentang jalan hidup Kim Jiyoung sebagai perempuan yang dilahirkan di Korea Selatan pada tahun 1982, yang sehari-harinya harus menerima perlakuan diskriminatif akibat adanya ketidaksetaraan gender yang mengkungkung Kaum Hawa di Korea Selatan. Kim Ji-young adalah seorang wanita karir pekerja keras yang terpaksa harus berhenti merintis karirnya demi menjadi ibu rumah tangga terutama setelah melahirkan anak. Mulai pekerjaan rumah hingga mengurus anak, justifikasi dari orang-orang sekitar, tekanan sosial dari masyarakat, keluarga pihak ayah dan pihak mertua, pelecehan seksual yang pernah dialami, stress akan rasa frustrasi yang terpendam, dan cita-cita yang terpaksa ia gantung menenggelamkannya dalam rutinitas hingga perlahan ia kehilangan jati dirinya. Depresi yang dialami berdampak pada kondisi psikis Kim Ji-young. Kesehatan mental Kim Ji-young melemah dan pada akhirnya harus rutin berkunjung ke psikiater.

Dikutip dalam jurnal Zainal Abidin Achmad (2020), the film is always entertaining to be the subject of research because the film has advantages in terms of emotional influence, the achievement of realism, and its popularity, especially if the film tells about women or raises gender issues (Carroll, 1990; Krahn, 2015; Murphy, 2015). Apabila diterjemahkan; film selalu menyenangkan untuk dijadikan target penelitian. Karena film memiliki keuntungan dalam hal pengaruh emosional, pencapaian realistis dan popularitasnya. Terutama bila film tersebut berbicara tentang perempuan atau mengemukakan isu gender. Oleh karena itu, bagaimana film sebagai media massa merefleksikan keadaan sosial realitas terkait isu gender "ketidaksetaraan gender (gender inequality)" di masyarakat dikemas dalam film Kim Ji-young, Born 1982 dipilih sebagai objek penelitian dilihat melalui kacamata analisi wacana kritis oleh Sara Mills.

Komunikasi massa merupakan proses organisasi media memproduksi serta menyebarkan pesan kepada publik atau khalayak. Organisasi media tersebut akan menyebarluaskan pesan dan akan mempengaruhi serta mencerminkan kebudayaan masyarakat dan informasi atau pesan tersebut akan mereka sajikan serentak kepada khalayak yang luas dan beragam. Janowitz dalam McQuail (2011:62) mengemukakan bahwa komunikasi massa terdiri atas lembaga serta teknik dari kelompok tertentu yang menggunakan teknologi (pers, radio, film dan sebagainya) untuk menyebarluaskan konten simbolik kepada khalayak yang besar, heterogen dan sangat tersebar.

Ciri media massa yang utama yaitu dapat menjangkau banyak orang. Terdapat pengirim yang disebut lembaga itu sendiri atau komunikator seperti reporter, jurnalis dan lain sebagainya yang bekerja dibawah lembaga serta penerima pesan yang dinamakan khalayak atau publik. Komunikasi bisa saja dilakukan melalui media maupun non media. Media terdiri dari media massa dan media non massa. Media massa yang telah kita ketahui terbagi menjadi dua, yaitu non periodik yang terdiri dari poster, 
ISSN. 2442-6962

Vol. 10. No. 1 (2021)

brosur, pengumuman billboard, lalu media masa periodik yang terdiri dari surat kabar, radio, majalah, televisi, film dan internet. Sedangkan media non massa yaitu surat, telegram, telepon dan lainnya.

Film merupakan salah satu bentuk media massa yang dikonsumsi oleh khalayak. Film memiliki peranan penting kepada khalayak atau penonton karena dapat membantu mereka untuk melakukan sebuah perubahan seperti identitas hingga transisi budaya. Film dibuat sedemikian rupa sehingga khalayak bisa saja terpengaruh oleh cerita adegan atau tindakan yang ada dalam film tersebut. Vera (2014:91) menungemukakan bahwa film merupakan salah satu media komunikasi massa karena merupakan bentuk komunikasi yang menggunakan saluran atau media dalam menyalurkan komunikator serta komunikan secara massal atau dalam jumlah besar dan tersebar dimana-mana, khalayaknya heterogen dan menimbulkan efek tertentu.

Dengan adanya perubahan yang menggunakan teknologi sebagai salah satu kekuasaan, film menjadi alat representasi serta distribusi yang menawarkan cerita, drama, musik hingga trik teknis. Film sebagai media massa merupakan bagian dari respon terhadap penemuan waktu luang, libur dari kerja dan sebuah jawaban atas tuntutan cara untuk menghabiskan waktu luang keluarga yang bersifat terjangkau serta (biasanya) terhormat. Film memberikan keuntungan budaya bagi kelas pekerja yang telah dinikmati oleh kehidupan sosial mereka yang cukup baik (McQuail, 2011).

Secara etimologis, feminisme dari bahasa latin yang memiliki arti perempuan. Feminisme dapat dipahami sebagai usaha yang memperjuangkan keadilan karena diskriminasi gender, dimana kita sering sekali menjumpai hal tersebut. Hodgson-Wright (2006) mengemukakan bahwa feminisme merupakan gerakan untuk menghadapi patriarki pada tahun 1550-1700 di Inggris. Hal ini dikarenakan bahwa perempuan hanyalah makhluk yang lemah sehingga membutuhkan perlindungan dari laki-laki yang dianggap lebih kuat.

Secara garis besar, feminisme terbagi menjadi tiga yaitu feminisme gelombang pertama, gelombang kedua, dan gelombang ketiga. Feminisme gelombang pertama yang dipelopori oleh Mary Wollstonecraft. Mary menuliskan karya klasik yang berjudul $A$ Vindication of The Right of Woman pada tahun 1792. merupakan gerakan yang hanya menuntut hak yang sama antara perempuan dan lakilaki dan bukan bertujuan untuk menyaingi laki-laki. Mary Wollstonecraft terus mendorong supaya anak perempuan memiliki hak yang sama dengan laki-laki untuk dapat bersekolah. Dia mengharapkan jika pendidikan ini dapat mengembangkan intelektual bagi anak perempuan sehingga akan menjadi individu yang mandiri terutama secara finansial (Richardson, 2002). Dalam feminisme gelombang pertama, sudah ada usaha dari beberapa perempuan untuk memperjuangkan haknya setelah menikah, lalu ada hak asuh anak ssetelah perceraian.

Sanders (2006) mengungkapkan bahwa feminisme gelombang pertama memiliki beberapa ambivalensi. Gerakan ini juga hanya memperjuangan perempuan lajang yang berasal dari kelas menengah dan yang paling diutamakan adalah memiliki intelektualitas tinggi. Lalu gerakan ini hanya menyangkut beberapa isu dan belum ada gerakan yang lebih luas lagi. Kemudian munculah kritik yang terjadi saat gerakan ini ada yaitu para feminis masih membutuhkan kaum laki-laki untuk mencapai segala tujuan yang mereka inginkan.

Setelah feminisme gelombang pertama, terdapat feminisme gelombang kedua yang ditandai dengan munculnya The Feminine Mystique (Fredian, 1963) kemudian kelompok Conscious Raising (CR) pada akhir tahun 1960an disertai dengan National Organization for Woman (NOW) (Thompson, 2010). Gelombang kedua muncul dikarenakan adanya rasa tidak puas terhadap gelombang pertama, oleh karena itu pada gelombang kedua gerakan yang lebih diutamakan yaitu isu yang dapat 
ISSN. 2442-6962

Vol. 10. No. 1 (2021)

mempengaruhi hidup perempuan, seperti reproduksi, pengasuhan anak, kekerasan seksual, seksualitas perempuan serta masalah domestisitas (Gillis, et.al., 2004).

Thornham (2006) berpendapat bahwa ciri yang identik dengan feminisme gelombang kedua baik di Inggris maupun Amerika yaitu adanya usaha merumuskan teori yang mampu melindungi seluruh perjuangan para feminis. Pada gelombang kedua, feminis menganggap bahwa conscious rising (pencerahan kondisi tertindasnya kaum perempuan oleh patriarki) adalah alternatif yang paling baik bagi perempuan untuk menyadarkan mereka dari keterkurungannya (O'Relly dan Porter, 2005). Beberapa kritikan muncul pada feminisme di gelombang kedua, seperti kritikan yang disampaika oleh kaum kulit hitam (khususnya perempuan), lesbian serta pekerja dan kemudian mereka membentuk gerakan radikal (Gubar, 2000: Jenaiti dan Groves, 2007). Ada juga anggapan bahwa feminisme liberal lebih mengutamakan kulit putih, gagal dalam isu kelas serta ras (Zaslow, 2009:28). Kemudian kritikan lainnya dilayangkan oleh kaum lesbian yang menuduh bahwa feminisme pada gelombang kedua ini mengesampingkan lesbianisme dan mengutamakan para heteroseksual (Thornham, 2006).

Selanjutnya yaitu feminisme gelombang ketiga. Fase ini muncul dikarenakan adanya beberapa hal yang mendorong munculnya fase ini, antara lain pada gelombang pertama yang dianggap terlalu rasis dan bersifat etnosentris yang hanya mewakili beberapa kelompok seperti perempuan kelas menengah berkulit putih serta adanya marginalisasi perempuan yang berasal dari kelompok lainnya. Kemudian diikuti oleh gelombang kedua yang dianggap belum betul-betul menyuarakan isu "sexual difference". Sementara terdapat pula teori yang berkembang diluar feminisme seperti post-modernisme, post-kulturalisme serta post-kolonialisme sehingga beriringan dengan berkembangnya feminisme itu sendiri. Permasalahan yang paling mendasar yang dialami feminisme pasca 1970 yaitu adanya dikotomi antara feminisme gelombang ketiga serta post-feminisme saat berkembangnya feminisme setelah gelombang kedua. (Faludi, 2006: Genz dan Brabon:2009) menjelaskan bahwa istilah post-feminisme muncul lebih awal pada artikel tahun 1920. Istilah tersebut digunakan sebagai pernyataan sikap "pro terhadap perempuan, namun tidak juga anti laki-laki", yang menjadi perayaan ketika feminisme gelombang pertama berhasil meraih hak pilih. Tong dalam Darma (2009:9) mengungkapkan bahwa feminis post-modern atau gelombang ketiga mempunyai pikiran untuk menghapuskan perbedaan yang ada diantara maskulin dan feminis, jenis kelamin laki-laki dan perempuan. Para feminis mencoba menghancurkan konsep kaum laki-laki yang mencegah wanita yang ingin memposisikan dirinya menggunakan pemikiran mereka dan tidak mengikuti pemikiran para kaum laki-laki.

Patriarki adalah sebuah sistem sosial dimana laki-laki menjadi sosok otoritas utama dalam organisasi sosial. Konsep ini digunakan dalam ilmu sosial terutama antropologi serta studi feminis (Bressler, Charles E. 2007). Kata patriarki sendiri lebih menonjolkan sistem budaya dimana kehidupan diatur sedemikian rupa oleh sistem "kebapakan". Patriarki sendiri merujuk pada masyarakat yang garis keturunan oleh bapak, hal ini juga menunjukkan ciri pada keluara tertentu bahwa yang mengatur, memimpin serta yang memerintah adalah kaum laki-laki.

Marla Mies, menganggap budaya patriarki sebagai sistem nilai yang memberikan tempat kepada laki-laki yang menjadikannya lebih tinggi kedudukannya dibandingan dengan perempuan, dan menyebar ke berbagai aspek sosial lainnya. Tentu saja bukan hal baru lagi apabila sebagian kaum lakilaki mendominasi kaum perempuan. Bukan hanya mendominasi diranah personal, tetapi hingga ekonomi, sosial, hukum dan lainnya. Terdapat dua bentuk patriarki yang dikemukakan oleh Sylvia Walby yaitu patriarki domestik dan publik. Patriarki domestik ditandai dengan melekatnya stereotipe terhadap perempuan, bahwa perempuan tugasnya hanya berputar pada rumah tangga. Sedangkan patriarki publik, terdapat enam hal yang memiliki kaitan dengan patriarki ini. Yang pertama adalah hubungan patriarki dalam rumah tangga, pekerjaan, kehidupan berbangsa bernegara, kekerasan oleh 
ISSN. 2442-6962

Vol. 10. No. 1 (2021)

kaum laki-laki, hubungan seksualitas serta yang terakhir adalah patriarki yang ada dalam institusi budaya.

Perbedaan gender yang terjadi antara kaum laki-laki dan perempuan merupakan suatu perjalanan yang cukup panjang. Perbedaan ini diperkuat bahkan yang lebih menyedihkan juga dikonstruksikan secara sosial, kultural hingga negara juga memberikan respon yang sama. Stereotipe inilah yang menyebabkan individu memiliki sikap serta tingkah laku yang mengaruskannya bertindak seperti apa yang telah dikonstruksikan tersebut. Perbedaan inilah yang menimbulkan ketidakadilan terhadap gender, adapun beberapa bentuk ketidakdilan gender yang terjadi diantara laki-laki dan perempan serta sering dijumpai sebagai berikut:

\section{Stereotipe (Pelabelan Negatif)}

Stereotipe merupakan ppelabelan yang memberikan kesan negatif kepada seseorang atau suatu kelompok tertentu berdasarkan anggapan yang keliru. Pelabelan menunjukkan adanya hubungan kekuasaan yang tidak seimbang yang bertujuan menguasai pihak tertentu. Pelabelan bisa dilakukan atas dasar gender dan menitikberatkan kepada perempuan, seperti contohnya perempuan yang dianggap cengeng, emosional, tidak rasional, tidak dapat mengambil keputusan yang dianggap penting hingga perempuan sebagai ibu rumah tangga sebagai pencari nafkah cadangan ataupun tambahan sedangkan laki-laki lah yang utama.

\section{Kekerasan}

Tindak kekerasan berasal dari fisik maupun non fisik yang dilakukan oleh jenis kelamin tertentu atau sebuah keluarga, masyarakat maupun negara terhadap jenis kelamin lainnya. Peran gender membedakan karakteristik yang ada pada perempuan yang dianggap feminim serta maskulin terhadap laki-laki. Hal ini yang menimbulkan sebuah pemikiran atau anggapan bahwa perempuan adalah makhluk yang lemah dan laki-laki sebaliknya. Anggapan ini juga yang membuat perempuan diperlakukan dengan semena-mena terutama kekerasan, seperti pemukulan, kekerasan dalam rumah tangga yang dimana istri menjadi korban serta pelecehan seksual dan eksploitasi seks terhadap perrempuan dan juga adanya pornografi.

\section{Marginalisasi}

Marginalisasi merupakan suatu proses mengesampingkan akibat dari perbedaan jenis kelamin yang menimbulkan kemiskinan. Memaginalisasikan kelompok dapat dilakukan dengan menggunakan asumsi gender seperti anggapan bahwa perempuan sebagai pecari nafkah tambahan. Adapun beberapa contoh yaitu perempuan yang bekerja di pabrik rentan terkena dampak PHK dikarenakan tidak adanya ikatan formal dengan perusahaan karena alasan gender. Lalu ada guru TK, perawat, pekerja konveksi dan sejenisnya yang dinilai rendah sehingga berpengaruh kepada gaji atau upah yang diterima.

\section{Sub Ordinasi}

Sub ordinasi merupakan penilaian yang dilakukan terhadap salah satu jenis kelamin yang dianggal rendah daripada jenis kelamin lainnya. Nilai yang ada dalammasyarakat telah memisahkan dan memilah peran gender antara laki-laki dan perempuan. Misalnya saja, perempuan dianggap memiliki tanggung jawab serta peran dalam kegiatan dalam sektor domestik atau reproduksi dan laki-laki memiliki peran di sektor publik serta produksi. Contohnya saja, banyak pekerja laki-laki dalam posisi atau bidang yang memerlukan peran dalam pengambilan keputusan tertentu dibandingkan dengan perempuan serta sedikitnya perempuan dalam dunia politik.

5. Beban Ganda 
ISSN. 2442-6962

Vol. 10. No. 1 (2021)

Beban ganda ini memiliki arti bahwa salah satu beban pekerjaan yang diterima oleh jenis kelamin tertentu lebih banyak daripada jenis kelamin lainnya. Peran perempuan seringkali dianggap statis dan permanen, seperti selain melayani suami, hamil, kemudian melahirkan, hingga menyusui, perempuan juga harus mengurus rumah dan juga terkadang juga bekerja untuk mencari tambahan nafkah. Perempuan diharuskan patuh dengan dalil kodratnya yang merupakan nilai dari masyarakat. hal inilah yang menunjukkan bahwa patriarki jelas menimbulkan ketidakadilan gender. Deskriminasi terhadap perempuani inilah yang mengharuskannya menerima stereotipe yang menyatakan bahwa perempuan adalah irasional, emosional, lemah lembut dan sebagainya.

Hal tersebut membuat kedudukan wanita tidak dapat sejajar dengan para laki-laki dan digambarkan secara terus terang membutuhkan atau menggantungkan laki-laki dalam hidupnya. Patriarki juga membuat perempuan kehilangan kesempatan dalam hampir seluruh ruang lingkup kehidupan seperti politik, pendidikan, fasilitas kesehatan hingga kehidupan yang layak.

\section{METODE PENELITIAN}

Metode penelitian yang digunakan dalam pembahasan kali ini yaitu metode deskriptif kualitatif dengan menggunakan pendekatan analisis wacana kritis oleh Sara Mills. Model analisis yang digagas oleh Mills ini menggambarkan para kaum perempuan dalam teks, yang hal ini cocok dengan penelitian pada film Kim Ji-Young, Born 1982. Analsis ini lebih bersifat makro dan tidak hanya menganalisis apa yang ada dalam teks saja. Beberapa aspek yang akan diteliti yaitu dalam segi produksi hingga kekuasaan yang menimbulkan konteks sosial politik. Kunci dari analisis ini ada "wacana" yang memiliki arti tulisan atau bahasa lisan dan dapat dimaknai lebih luas dikarenakan pengaruh perkembangan media dan budaya. Adapun sesuatu yang dapat menghasilkan makna yaitu film, poster, iklan, video klip dan sebagainya. Penelitian ini melihat suatu sudut pandang yang berbeda yang ada dalam film Kim JiYoung, Born 1982, kemudian mengembangkan dan mencari apa ideologi yang terdapat dalam film ini.

Pada penelitian ini, ditekankan bagaimana perempuan digambarkan dalam sebuah teks. Maka dari itu, analisis wacana model Sara Mills cocok digunakan walaupun degan sedikit penyesuaian karena biasanya analisis Mills digunakan pada media cetak. . Beberapa hal yang mempengaruhi teks antara lain norma sosial budaya, ideologi, sejarah, kekuatan ekonomi, gender, rasisme dan lainnya.

Sara Mills lebih memperlihatkan bagaimana aktor ditampilkan dalam teks dan bagaimana para audiens mengidentifikasikan serta menempatkan mereka dalam penceritaan teks tersebut (Eriyanto, 2001). Konsep posisi pembaca menurut Mills tidak ditempatkan secara langsung oleh penulis tetapi berlawanan. Pertama, teks menampilkan wacana bertingkat dengan kebenaran secara hirarkis serta sistematis yang berada di tengah, sehingga pembaca mengidentifikasikan mereka dengan karakter yang ada dalam teks (Eriyanto, 2001). Kemudian yang kedua yaitu kode budaya atau nilai budaya yang ada dalam benak audiens atau pembaca ketika menafsirkan teks tersebut. Apabila yang dikaji adalah film, menurut analisis wacana model Mills yaitu film tidak dibuat secara terpisah dengan masyarakat yang memiliki peran sebagai audiens. Dapat diartikan bahwa film dibuat dengan melihat bagaimana kondisi masyarakat yang saat itu terjadi serta konteks dari masyarakat itu sendiri.

\section{HASIL DAN PEMBAHASAN}

Film dengan judul "Kim Ji-young, Born 1982" tayang di negara asalnya, Korea Selatan pada tanggal 23 Oktober 2019, dan pada 20 November 2019 dirilis di bioskop Indonesia. Film ini merupakan hasil adaptasi dari sebuah novel yang memiliki judul sama yang terbit tiga tahun sebelumnya yaitu pada 2016. Analisi wacana kritis milik Sara Mills menitik beratkan perhatiaannya pada bagaimana wanita di representasikan dalam sebuah teks. Dalam analisis wacana kritis menurut Mills ini melihat bahwa wanita direpresentasikan dalam posisi yang salah, dan tidak jarang wanita tidak diberi kesempatan 
ISSN. 2442-6962

Vol. 10. No. 1 (2021)

untuk membela diri. Maka dari itu, metode ini akan digunakan untuk melihat bagaimana wanita direpresentasikan dalam film "Kim Ji-young, Born 1982". Untuk membedah film ini dengan menggunakan prinsip analisis wacana menurut Sara Mills dapat dengan melihat bagaimana kedudukan aktor yang diperlihatkan didalam film. Selain itu, Sara Mills juga akan memperlihatkan bagimana kedudukan pihak yang menjadi subjek dan yang menjadi objek didalam film ini.

Yang ingin dilihat dalam posisi subjek-objek, ialah siapa yang diposisikan sebagai pencerita (subjek) dan siapa yang akan menjadi objek untuk diceritakan. Selain itu juga untuk melihat bagaimana wanita direpresentasikan dalam film ini. Tidak hanya berhenti disitu, pada penelitian ini juga untuk melihat wacana serta ideologi apa yang akan diangkat.

\section{a. Posisi Subjek (Produser) dan Objek dalam Film "Kim Ji-young, Born 1982"}

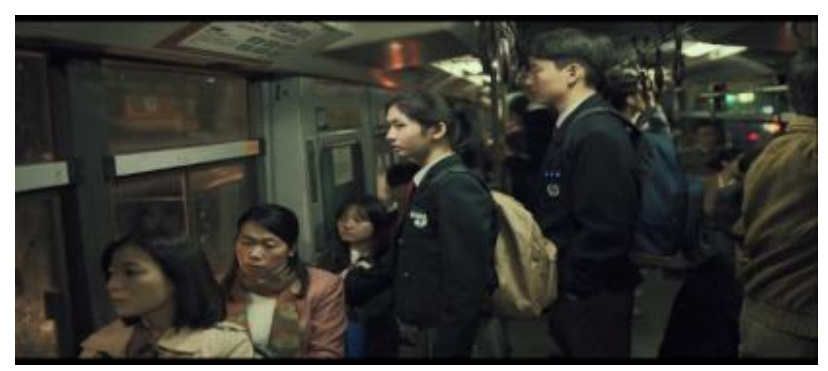

gambar 1. kim ji young diikuti dari jarak dekat oleh laki-laki tidak dikenal

\section{sumber 1: penggalan film kim ji young}

Pada gambar tersebut memperlihatkan adegan dimana terdapat Ji-young saat masih sekolah, ketika dia baru saja pulang dari les malam hari dan menggunakan transportasi umum. Pada gambar diatas terlihat Ji-young berada di dekat laki-laki yang sama-sama menggunakan seragam sekolah. Laki-laki tersebut mengikuti dan terus mendekati Ji-young bahkan saat berada di transportasi umum. Laki-laki tersebut terlihat memiliki jarak yang termasuk cukup intim dan tanpa persetujuan dari Ji-young sehingga Ji-young terlihat tidak nyaman. Hingga akhirnya terdapat penumpang lain yang menyadari bahwa Ji-young mengalami hal yang kurang nyaman dan berusaha membantu dengan meminjamkan ponsel miliknya agar bisa menghubungi ayah Ji-young. Setelah turun dari transportasi umum, laki-laki tersebut masih mengikuti Ji-young, hingga terdapat penumpang yang menyadari ketidaknyaman Ji -young di Bus, ikut turun dan mengahampiri Ji-young hingga akhirnya membuat laki-laki tersebut pergi dan ayah dari Ji-young tiba menemui Ji-young. Di sini karakter Ji-young digambarkan lemah dan menarik perhatian serta hasrat laki-laki.

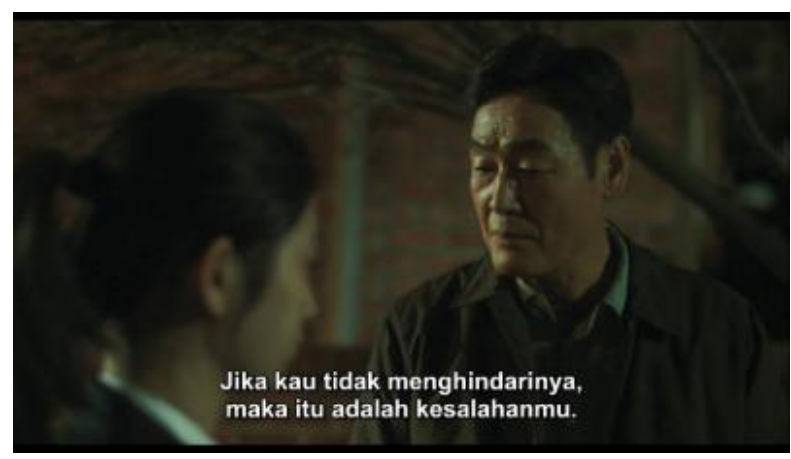

gambar 2. ayah ji young menyalahkan pakaian ji young sehingga dia diikuti laki-laki tidak dikenal sumber 2: potongan film kim ji young, born 1982

Teks : 
ISSN. 2442-6962

Vol. 10. No. 1 (2021)

Ayah Ji-young: Mengapa pergi ke tempat les yang begitu jauh sekali? Tidak usah pergi lagi

Ji-young hanya mengangguk

Ayah Ji-young: Berpakaianlah yang benar. Rokmu terlalu pendek. Dan jangan tersenyum kepada siapapun

Ji-young: Tidak! Aku bahkan tidak ingat.

Ayah Ji-young: Mengapa kau tidak ingat? Kau harus berhati-hati tetaplah berwaspada dan hindari masalah. Jika ada batu meggelindingimu apa kau akan diam berdiri saja? Jika kau tidak menghindarinya, maka itu adalah kesalahanmu. Mengerti?

Pada percakapan serta gambar diatas merupakan adegan saat Ji-young dan ayahnya berjalan bersama menuju rumah. Pada teks diatas menunjukkan bahwa yang terjadi pada Ji-young saat dibuntuti oleh seorang laki-laki direspon oleh sang ayah dengan menyatakan bahwa yang terjadi tidak lain karena kesalahan Ji-young juga, akibat, dari pakaiannya yang dikenakan yaitu dari roknya yang dianggap terlalu pendek. Hal tesebut dapat dimaknai apabila terjadi kejahatan sexual pada wanita, tidak lain penyebabnya adalah dari korbannya sendiri, selain itu juga dikatakan bahwa wanita lemah dengan tidak memberontak apabila terjadi suatu kejahatan. Oleh sebab itu wanitalah yang disalahkan, padahal wanita yang menjadi korban sesungguhnya. Pada adegan tersebut disiratkan bahwa laki-laki bisa mengendalikan perempuan, dimana ayah Ji-young mengatakan bahwa Ji-young juga bersalah apabila terjadi suatu tindak kejahatan sexual, akibat dari tindakan dan pakaian yang dipakai oleh Ji-young dan ia tidak dapat mengelak. Disini diperlihatkan bahwa perempuan dapat dikendalikan, penjelasan tersebut merupakan patriarki. Sutradara film ini ikut andil dalam memproduksi wacana dalam film. Film ini dibuat untuk mempelihatkan pada penonton bahwa perempuan ditempatkan sebagai objek yang lemah dan sebagai pemuas hasrat laki-laki serta sebagai objek yang dapat dikendalikan oleh laki-laki. Sehingga membuat penonton dapat menemukan sudut pandang ideologi patriarki, serta membantu penonton untuk memberi arti dari feminitas.

\section{b. Posisi Perempuan Direpresentasikan dalam Film "Kim Ji-young, Born 1982"}

Pada film Kim Ji Young, Born 1982 ini wanita direpresentasikan mendapat perilaku yang berbeda dengan lelaki, sehingga mengalami bias gender. Di film ini wanita digambarkan mendapatkan ketimpangan pada kehidupan sosial, budaya, ekonomi, maupun politik. Ketimpangan yang dialami oleh wanita ini disebut ketidakadilan gender atau gender inequality. Ketidakadilan gender ini terdiri dari lima aspek yaitu stereotip, marginal, sub ordinasi, kekerasan, dan beban ganda. Dimana kelima hal itu terdapat dalam film ini.

\section{Stereotipe}

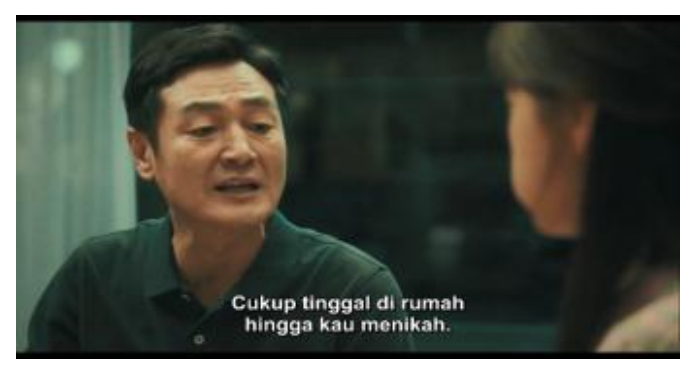

Gambar 3. ayah ji young menunjukkan stereotipe bahwa wanita bekerja diranah domestik saja.

Sumber 3: potongan film kim ji young, born 1982

Teks :

Ji-young: Aku tidak akan pergi. Aku belum mendapatkan pekerjaan.

Ibu Ji-young: Nanti kau akan menyesal karena tidak mempunyai foto wisuda. 
ISSN. 2442-6962

Vol. 10. No. 1 (2021)

Ji-young: Lupakan. Aku tidak akan menyesalinya!

Ibu Ji-young: Ji Young..

Ayah Ji-young: Cukup. Kalau begitu, hentikan semuanya. Cukup tinggal diruma hingga kau menikah. Itu cocok untukmu!

Pada teks diatas ketika keluarga Ji-young sedang makan malam, dan membahas mengenai Ji-young yang tidak ingin menghadiri wisudanya. Ketika perbedaan pendapat antara Ji-young dan ibunya mengenai untuk hadir atau tidak ke acara wisuda Ji-young, ayah Ji-young mengatakan, "Cukup. Kalau begitu, hentikan semuanya. Cukup tinggal di rumah hingga kau menikah. Itu cocok untukmu!'. Dalam teks tersebut diperlihatkan bahwa disini wanita distereotipkan untuk tetap berada dirumah, dan dianggap tidak berkompeten untuk bisa bekerja. Menurut Silvia Walby, 1998: 20, wanita memang dilabelkan untuk menduduki Private Patriarki atau yang biasa disebut peran domestik dimana wanita lebih ditekankan untuk menjalankan pekerjaan rumah tangga saja (rokhimah , 2014). Rasa optimis yang dimiliki Ji-young setelah menyelesaikan kuliahnya dihancurkan dengan respon yang diberikan oleh sang ayah dengan menyuruh sang anak agar hanya berada dirumah saja hingga menikah.

\section{Marginal}

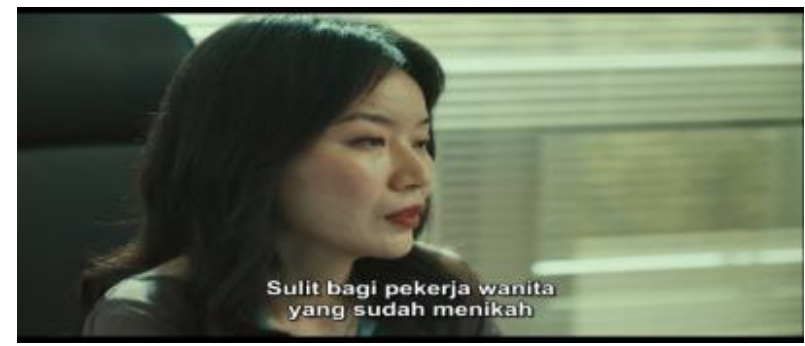

gambar 4. wanita terkena dampak pemiskinan ekonomi karena terkena proses peminggiran sumber 4: potongan film kim ji young, born 1982

Teks :

Ji-young: Mengapa kau tidak memasukkanku ke dalam tim-mu?

Kim Eun Sil : Bukan karena kau kurang sesuatu. Perusahaan menginginkan tim jangka panjang lebih dari 5 tahun. Sulit bagi pekerja wanita yang sudah menikah dan menjadi orang tua. Bahkan jika aku melibatkanmu itu akan sulit bagimu.

Ji-young: Aku tahu aku bisa bekerja dengan baik.

Pada teks dan gambar diatas, "Bukan karena kau kurang sesuatu. Perusahaan menginginkan tim jangka panjang lebih dari 5 tahun. Sulit bagi pekerja wanita yang sudah menikah dan menjadi orang tua. Bahkan jika aku melibatkanmu itu akan sulit bagimu”. film sebagai media dalam menyampaikan bahwa wanita terkena proses peminggiran dalam sektor ekonomi yang mengakibatkan kemiskinan. Dalam film ini Ji-young yang merupakan seorang wanita tidak mampu mendapatkan kedudukan sebagai tim perencanaan akibat faktor reproduksinya yaitu mengenai konsekuensi dari hamil, dan melahirkan yang akan terjadi, karena pada saat itu Ji Young diceritakan telah menikah. Secara tidak langsung menunjukkan bahwa sedang terjadi proses pemiskinan yang beralasan gender.

\section{Sub ordinal}




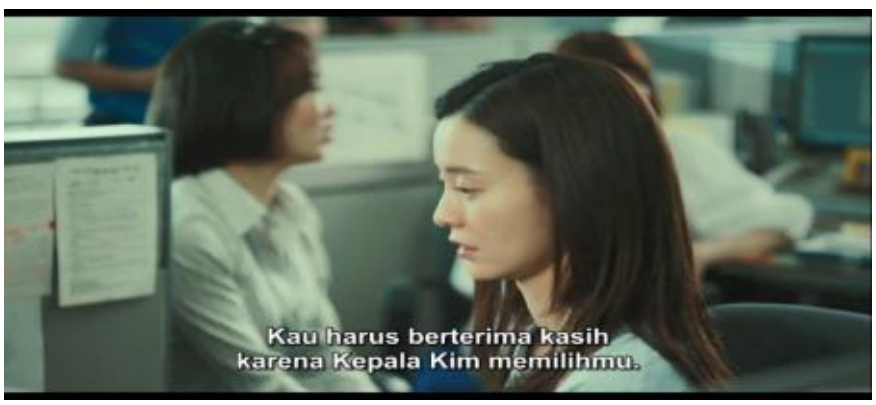

gambar 5. hanya pegawai laki-laki yang dipilih untuk posisi terbaik sumber 5:potongan film kim ji young, born 1982

Teks :

Hye Soo : Selamat.

Byung Sik : Apa?

Hye Soo : Kau masuk dalam tim perencanaan.

Ji-young : Selamat.

Byung Sik: Aku tidak mau.

Hye Soo : Kau harus berterima kasih, karena kepala Kim memilihmu. Dia hanya memilih lelaki.

Pada teks tersebut, dimana Hye Soo mengatakan "Kau harus berterima kasih, karena kepala Kim memilihmu. Dia hanya memilih lelaki." Menunjukkan bahwa penilaian mengenai wanita dianggap lebih rendah daripada laki-laki. Sehingga wanita tidak dapat ditempatkan pada posisi yang sama dengan laki-laki, serta wanita masih kurang diapresiasi dalam pekerjaannya. Meskipun kinerja yang dimiliki oleh wanita bagus, namun akan tetap dianggap lebih rendah daripada lakilaki. Oleh sebab itu, dalam adegan tersebut, dipertontonkan betapa timpangnya posisi yang diperoleh oleh wanita dalam sektor publik. Selain itu, pemilik keputusan dalam perusahaan juga laki-laki.

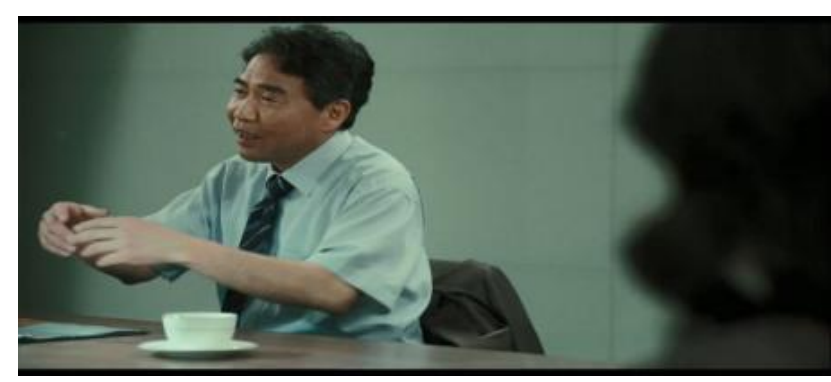

gambar 6. jabatan tertinggi selalu dipegang oleh laki-laki

sumber 6:potongan film kim ji young, born 1982

Gambar diatas merupakan seorang direktur dari perusahaan tempat Ji-young bekerja, dimana posisi tersebut ditempati oleh seorang laki-laki. Selain itu, wanita selalu memiliki kedudukan yang lebih rendah dalam posisi di kantor tersebut daripada laki-laki.

\section{Kekerasan (Violence)}




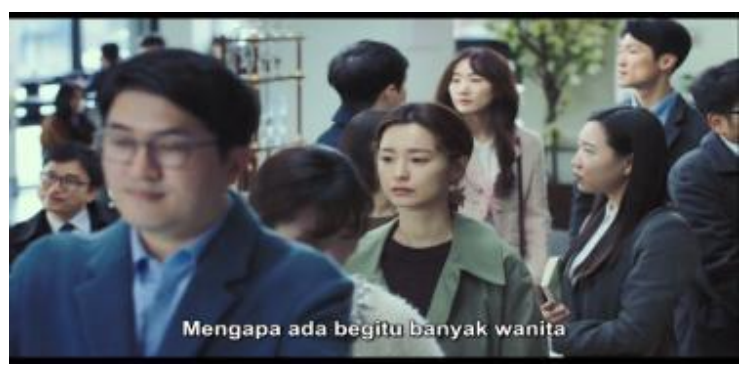

gambar 7. laki-laki melakukan kekerasan verbal kepada wanita di sebuah cafe sumber 7:potongan film kim ji young, born 1982

Teks :

Laki-laki yang bersama dua orang temannya : Menyebalkan sekali. Mengapa tidak minum kopi dirumah? Bagaimana dia bisa membersihkan itu? Dasar lamban seperti cacing.

Teman wanita yang bersama laki-laki tersebut : Dia bisa mendengarmu.

Laki-laki yang bersama dua orang temannya : Namun, dia tidak tahu malu.

Teman laki-laki yang bersama laki-laki tersebut : Sayang sekali.

Laki-laki yang bersama dua orang temannya : Mari minum diluar.

Teman wanita yang bersama laki-laki tersebut : Bukankah diluar dingin?

Laki-laki yang bersama dua orang temannya : Masih lebih baik.

Pada teks tersebut diperlihatkan bahwa laki-laki tidak dikenal yang sedang sama-sama berada dalam sebuah café, melakukan kekerasan verbal yang berisikan "Menyebalkan sekali. Mengapa tidak minum kopi dirumah? Bagaimana dia bisa membersihkan itu? Dasar lamban seperti cacing." Dan juga "Namun, dia tidak tahu malu." Kalimat tersebut ditujukan kepada Ji-young yang sedang berusaha membersihkan kopi yang tidak sengaja ditumpahkan akibat fokus yang terpecah oleh anaknya yang sedang menangis. Penggunaan kalimat tersebut sangat kasar, dan sangat menyepelekan sorang wanita yang sekaligus telah menjadi ibu. Kalimat tersebut dapat masuk dalam kekerasan verbal, walaupun tidak ada luka secara fisik. Kekerasan verbal tetaplah sebuah kekerasan, seerta kekerasan yang dilakukan salah satu jenis kelamin yaitu laki-laki terhadap perempuan.

\section{Peran Ganda}

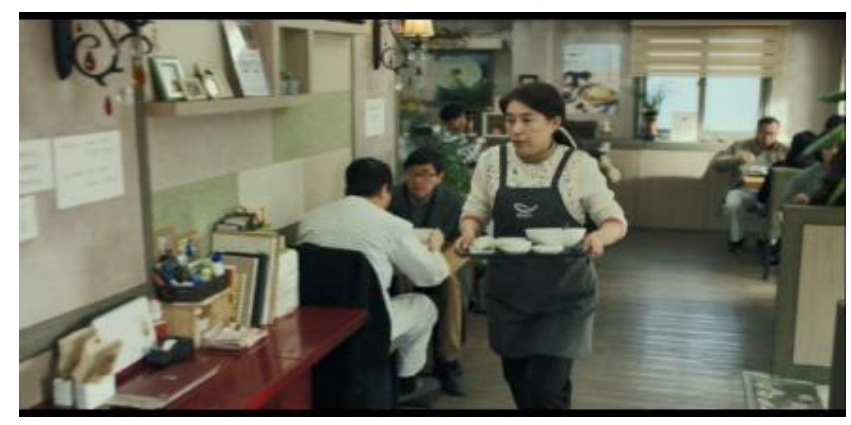

gambar 8. ibu ji young bekerja di sebuah restourant sumber 8:potongan film kim ji young, born 1982 


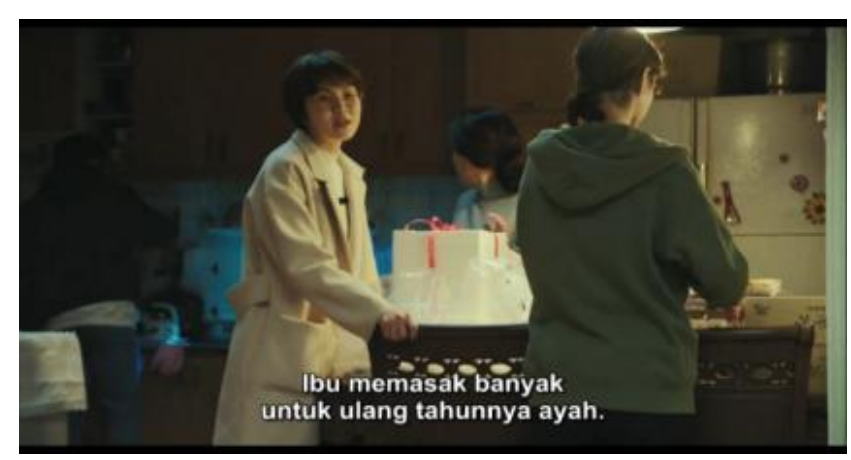

gambar 9. ibu ji young melakukan pekerjaan rumah tangga sumber 9:potongan film kim ji young, born 1982

Teks :

Bibi Ji-young: Ibumu bisa saja memasak untuk makan bersama.

Kim Eun Young : Ibu memasak banyak untuk ulang tahunnya ayah. Bukankah konyol jika ibu memasak untuk pesta ulang tahunnya sendiri.

Pada gambar diatas diperlihatkan bahwa ibu dari Kim Ji-young juga bekerja di sebuah restaurant. Akan tetapi ketika ia berada dirumah, tidak dapat meninggalkan tanggung jawabnya sebagai ibu rumah tangga, dan masih harus menyiapkan segala sesuatu dirumah. Sebagaimana saat ulang tahunnya, Eun Young sebagaimana anak pertama menyebutkan bahwa ibunya juga harus memasak banyak saat ayahnya mengadakan pesta ulang tahun. Dengan uraian tersebut tersirat bahwa yang bekerja atau memiliki peran dalam sektor publik juga harus mengerjakan pekerjaanpekerjaan domestik. Artinya beban yang dilimpahkan kepada wanita lebih banyak daripada beban yang dimiliki oleh laki-laki.

\section{KESIMPULAN}

Setelah diteliti dan dicermati film Kim Ji-young, Born 1982 mengenai prinsip yang diusung oleh Sara Mills, sehingga dapat dilihat bagaimana posisi dari subjek yaitu sutradara dari film ini dalam mengolah serta menyebarkan wacana mengenai wanita dalam film. Untuk memikat perhatian dari penonton, perempuan diperlihatkan sebagai sosok yang lemah dan mudah dikendalikan oleh laki-laki. Selain itu wanita juga dianggap sebagai pemuas hasrat dari laki-laki, dan ikut membantu dalam menyampaikan ideologi patriarki serta membantu penonton untuk memberi arti dari "feminitas". Kemudian, posisi wanita direpresentasikan pada film ini sebagai wanita yang mengalami banyak ketimpangan dalam kehidupan diberbagai sektor yaitu social, budaya, ekonomi, maupun politik yang diakibatkan dari ketidakadilan gender. Wanita dalam film ini diperlihatkan bahwa mereka mengalami berbagai macam hal yang menempatkan posisi wanita tidak cukup adil daripada laki-laki. Wanita mengalami marjinalisasi, sub ordinasi, kekerasan baik fisik maupun non fisik, stereotip yang harus diterima, serta beban ganda apabila seorang wanita juga bekerja pada sektor publik.

Film ini memberitahukan bagaimana posisi perempuan saat ini, dalam berbagai aspek kehidupan. Dengan adanya film ini, diharapkan penonton dapat lebih bijak dan tentunya terdapat perubahan bagaimana wanita harus diberikan kedudukan yang layak dalam kehidupan. Serta dengan adanya film ini diharapkan dapat terjadi perubahan tindakan yang secara sadar maupun tidak, yang merupakan hasil dari pemahaman akan film tersebut. Karena dengan film, dapat untuk mempengaruhi emosional dari penontonnya. Selain itu, film juga bisa dijadikan sebagai sebuah visualisasi dari realitas sosial suatu masyarakat. Selain juga film, mengandung fungsi informasi, edukasi dan persuasif. Maknamakna mengenai bagaimana perempuan diperlihatkan dalam konstruk sosial sebagai sosok yang lemah dan tidak terelakkan dari ketimpangan yang merupakan hasil ketidakadilan gender harus mulai untuk 
ISSN. 2442-6962

Vol. 10. No. 1 (2021)

dibongkar. Dengan film, dapat dijadikan sebagai sebuah wadah untuk bisa mempersuasif masyarakat agar dapat mengubah realitas social mengenai ketidakadilan gender di kehidupan.

\section{DAFTAR PUSTAKA}

Achmad ZA. (2020). Construct of Women, Violence, and Liberation of Identity in "Fiksi" Film. LENTERA: Journal of Gender and Children Studies, 2(1), 3. Retrieve from https://journal.unesa.ac.id/index.php/JOFC/article/view/8203/0

Chornelia, Y. H. (2013). Representasi Feminisme Dalam Film "Snow White and the Huntsman". Jurnal e-Komunikasi, 1(3). Retrieve from REPRESENTASI FEMINISME DALAM FILM "SNOW WHITE AND THE HUNTSMAN" | Chornelia | Jurnal e-Komunikasi (petra.ac.id)

Dewi ME., \& Nugroho C. (2017). Wacana Ketidakseteraan Gender pada Film Siti. e-Proceeding of Management 4(3), 3055-3062. Retrieve from https://repository.telkomuniversity.ac.id/pustaka/files/137184/jurnal_eproc/wacanaketidaksetaraan-gender-pada-film-siti-a-discrouse-of-gender-inequality-in-siti-movie.pdf

Farnisari M., \& Sudrajat A. (2013). Bias Gender dalam Film Seri Korea "Sungkyunkwan Scandal". $\begin{array}{llll}\text { Paradigma, } & \text { 1(2), } & \text { R-15. } & \text { Retrieve }\end{array}$ https://jurnalmahasiswa.unesa.ac.id/index.php/paradigma/article/view/2465/5561

Fauzan, U. (2014). Analisis Wacana Kritis dari Model Faiclough Hingga Mills. Jurnal Pendidik, 6(1). Retrieve from http://www.academia.edu/download/47096548/Analisis_Wacana_Kritis_dari_Model_Faircl. pdf

Kartika, BA. (2015). Mengapa Selalu Harus Perempuan: Suatu Konstruksi Urban Pemenjaraan Seksual Hingga Hegemoni Maskulinitas dalam Film Soekarno. Journal of Urban Society's Art, 2(1), 36. Doi: https://doi.org/10.24821/jousa.v2i1.1268

Mc. Quail, D. (2011). Teori Komunikasi Massa edisi 6 (Vol. satu). Jakarta: Salemba Humanika.

Meutia, F. S. (2018). MEMBACA “TINUNG” DALAM FILM CA BAU KAN: ANALISIS WACANA KRITIS DALAM PERSPEKTIF GENDER. Jurnal Dakwah Tabligh, 18(1), 131-145. Retrieve from https://jurnalmahasiswa.unesa.ac.id/index.php/paradigma/article/view/2465/5561

Omara, A. (2004). Perempuan, Budaya Patriarki dan Representasi. Mimbar Hukum, 2(2004). Retrieve from http://i-lib.ugm.ac.id/jurnal/detail.php?dataId=2625http://ilib.ugm.ac.id/jurnal/detail.php?dataId=2625

Rokhimah, S. (2014). Patriarkhisme Dan Ketidakadilan Gender. Jurnal Muwazah, 6(1). Retrieve from http://e-journal.iainpekalongan.ac.id/index.php/Muwazah/article/view/440

Sobari, T., \& Faridah, L. (2017). Model sara mills dalam analisis wacana peran dan relasi gender. Semantik, 5(1), 89-99. Doi: https://doi.org/10.22460/semantik.v5i1.p89\%20-\%2099

Sirojul. (2019, 20 November). Sinopsis Film Korea Kim Ji-young, Born 1982 di Bioskop Hari Ini. Tirto.id. diakses dari https://tirto.id/sinopsis-film-korea-kim-ji-young-born-1982-di-bioskophari-ini-elZA pada 28 Oktober 2020, pukul 21.36

Surwati, C. H. D. (2012). Konstruksi Feminisme dalam Film Indonesia (Analisis Wacana Kritis Konstruksi Feminisme dalam Film Indonesia Karya Sutradara Nia Dinata). Jurnal Komunikasi Massa, l(1). Retrieve from https://www.jurnalkommas.com/docs/Ch\%20Heny\%20artike1\%20jurnal\%202012_revisi.pdf 
JISIP: Jurnal Ilmu Sosial dan Ilmu Politik

ISSN. 2442-6962

Vol. 10. No. 1 (2021)

Tutiasri RP., Yuliani ER., Purnamasari NP., \& Putri CO. (2020). Analisis Resepsi Budaya Menjenguk Orang Sakit dalam Film Pendek Tilik pada Ibu-Ibu di Kabupaten Bantul. Jurnal VoxPop. 2(1), 103. Doi: https://doi.org/10.33005/voxpop.v2i1.85

Walby, S.. (1998). Theorizing Patriarchy, Oxford:Blackwell, 20. Diakses dari 1990_Walby_Theorising_Patriarchy_book_Blackwell.pdf (lancs.ac.uk) 